\title{
A new record of Tragulus versicolor (Artiodactyla, Tragulidae) from Vietnam, and its sympatric occurrence with T. kanchil
}

\author{
German V. Kuznetsov \& Alex V. Borissenko
}

\begin{abstract}
The first record ofTragulus versicolor Thomas, 1910 outside its type locality is described. One specimen was collected in the vicinity of Dak Rong and Boun Luoi, $20 \mathrm{~km}$ north of Kan Nack (Gia Lai Province, Central Vietnam), collected in 1990 and deposited in the Zoological Museum of Moscow University. Peculiar external characters (pelage coloration pattern) indicate its authenticity from the sympatrically occurring T. kanchil (Raffles, 1821). Certain aspects of morphological differences between the two species and conservation issues relevant to the new finding are being discussed.
\end{abstract}

KEY WORDS: Tragulus versicolor, T. kanchil, Vietnam, new record.

German V. Kuznetsov [sevin@orc.ru], A.N. Severtsov Institute of Ecology and Evolution of the Russian Academy of Sciences, Leninskii pr. 33, Moscow 119071, Russia; Alex V. Borissenko [borissenko@zmmu.msu.ru], Zoological Museum of Moscow State University, Bolshaya Nikitskaya ul. 6, Moscow 125009, Russia.

\section{Новая находка Tragulus versicolor (Artiodactyla, Tragulidae) во Вьетнаме и симпатрическое обитание этого вида с T. kanchil}

\author{
Г.В. Кузнецов, А.В. Борисенко
}

\begin{abstract}
РЕЗЮМЕ: Описана первая находка чепрачного оленька Tragulus versicolor Thomas, 1910, известная за пределами типового местонахождения этого вида. Один экземпляр добыт в 1990 г. в окрестностях Дак Ронга и Буон Лыоя, в 20 км севернее пос. Кан Нак (провинция Зя Лай, Центральный Вьетнам), и депонирован в Зоологическом музее Московского Университета. Особенности внешнего строения (характер окраски шкуры) указывают на его четкое отличие от симпатрически обитающего малого оленька T. kanchil (Raffles, 1821). Обсуждены некоторые аспекты морфологических различий этих видов и вопросы охраны, связанные с новой находкой.
\end{abstract}

КЛЮЧЕВЫЕ СЛОВА: Tragulus versicolor, T. kanchil, Вьетнам, новая находка.

\section{Introduction}

The latest taxonomical revision of the genus Tragulus (Meijaard \& Groves, 2004) suggested the existence of six species belonging to three species groups, two of which have been reported from the Eastern part of mainland Southeast Asia. The most common and widespread species in this part of the range is T. kanchil (Raffles, 1821) from the "javanicus" species group, whereas the second species, T. versicolor Thomas, 1910 was hitherto known by six specimens, all of them having originated from the vicinity of Nha Trang, Vietnam in the beginning of the 20th century (E. Meijaard, pers. comm.). Distinctive features of pelage coloration and craniometrical characters of this named form persuaded the authors to exclude it from the synonymy of $T$. napu where it was previously allocated and assign it to a separate species group.

During the field work on Tay Nguyen Plateau in the period from 1978 to 1993 within the framework of joint Vietnamese-Russian expeditions, the senior author examined in the field and collected several specimens of Tragulus, most of them shot or snared by local hunters. Several of these specimens, all initially identified as $T$. javanicus were deposited with the Theriological Section, Zoological Museum of Moscow University, Moscow (ZMMU). Recent reexamination of collection materials deposited by these expeditions revealed the presence of an unusually colored specimen, matching in external characters the description of $T$. versicolor. The availability of a substantial series of the more common T. kanchil from the same locality, as well as field records made by the senior author, provided the opportunity to make a comparative assessment of sympatrically and contemporarily occurring representatives of the two species.

\section{Description and Discussion}

The specimen of $T$. versicolor (ZMMU catalogue number S-151301, unmounted skin only) is an adult male obtained from local hunters on 16 January 1990 nearby Tra River (tributary of Ba River) in the vicinity of Dak Rong and Buon Luoi, $20 \mathrm{~km}$ north of Kan Nack (Gia Lai Province, Central Vietnam) $\left(14^{\circ} 20^{\prime} \mathrm{N} 108^{\circ} 36^{\prime} \mathrm{E}\right)$ at $\sim 500 \mathrm{~m}$ ASL. Apparently it was shot in the head, therefore the skull was lost and the skin of the head is badly damaged. Nevertheless, the characters of pelage 


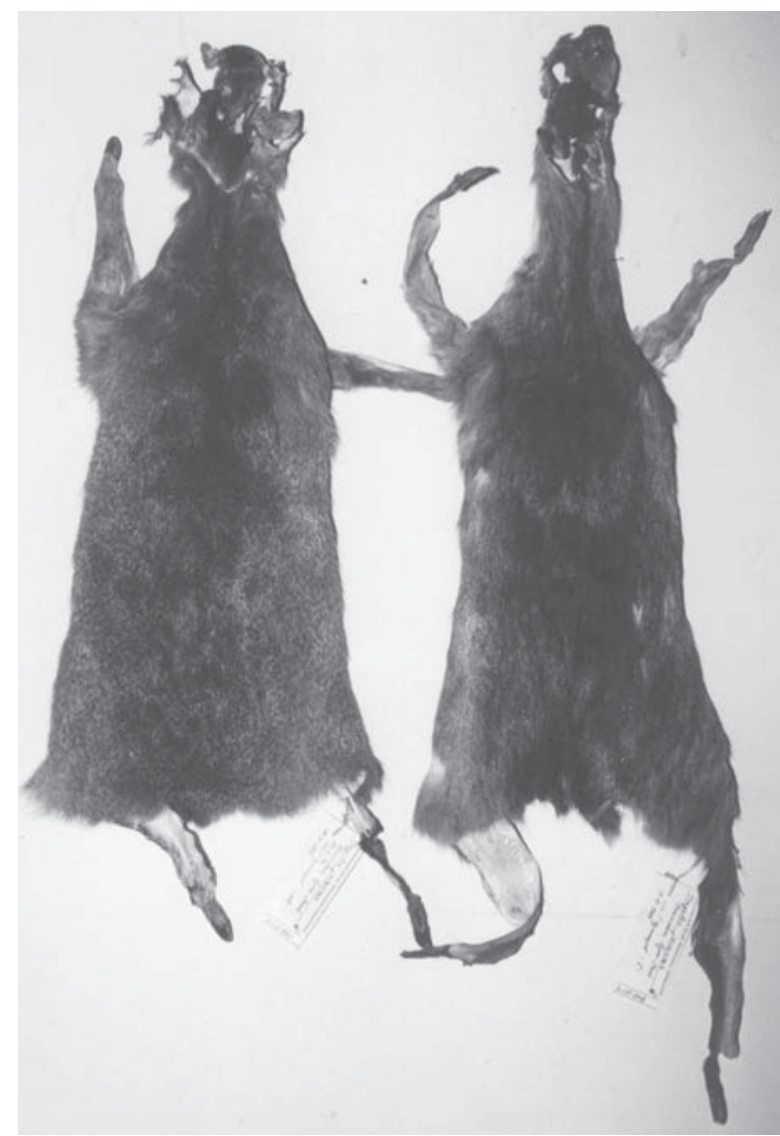

Figure 1. Dorsal view of the skin of Tragulus versicolor from Buon Luoi (ZMMU S-151301, male, left), compared to a specimen of T. kanchil (ZMMU S-151302, male, right) from the same locality.

structure and coloration pattern allow placing it unambiguously with $T$. versicolor. The upperparts of the specimen have a characteristic shabrack appearance (Fig. 1). Fur on the back is uniformly grayish and relatively dense; the hairs are conspicuously tipped with white. The area of the neck and shoulders, although too quite uniform in color, is visibly separated from the back in having more brownish and less dense fur, the sides of the neck possess a somewhat different pattern of pelage structure. In general, the fur of the neck appears to have a coarser, less spiny appearance, as compared to that of T. kanchil. The belly is pure white, with a pronounced border line with the grayish color of the back and no specific color pattern on the flanks (Fig. 2). The white area of the underparts continues uninterrupted from the chin towards the groin area, and there is no transverse brownish collar below the throat. Also, there are no darker-colored markings along the sides and midline of the belly, which are characteristic of T. kanchil.

Specimens of T. kanchil from the same locality (a total of 16 specimens of both sexes examined, including five specimens deposited in the ZMMU) were collected during various seasons of 1980 through 1993. All examined skins or dead animals $(n=16)$ were of typical

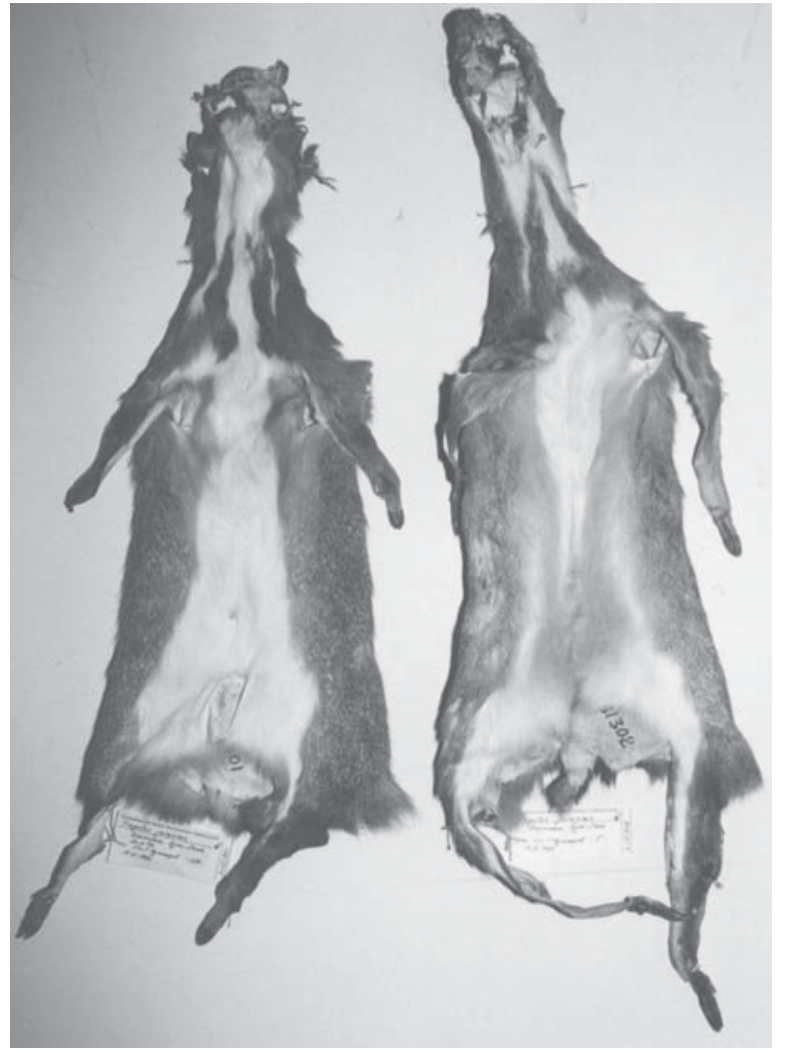

Figure 2. Ventral view of the skin of Tragulus versicolor from Buon Luoi (ZMMU S-151301, left), compared to T. kanchil (ZMMU S-151302, right) from the same locality.

appearance, with more or less uniform reddish-brown colored upperparts, sometimes with a faint mid-dorsal stripe along the neck. The underparts are white with a prominent transverse brown collar across the throat and conspicuous yellowish markings along the midline of the belly and in the groin area. This coloration pattern is retained in the skins of four adult males collected in the same locality during December and January, rejecting the possibility that the observed differences may be attributable to seasonal changes in pelage color. The unusual coloration of the one specimen now referred to T. versicolor was noted in the field journal of the senior author, who examined the animal post-mortem and prepared the study-skin, however, this has not been given any taxonomical interpretation.

The notion that $T$. versicolor is on the average larger than T. kanchil in skull dimensions (Meijaard \& Groves, 2004 ) is not corroborated by our original comparative data on weight and external measurements of sympatrically occurring specimens of the two species in the northern part of Tay Nguyen Plateau. As could be seen from Tab. 1, the specimen of $T$. versicolor is evidently smaller than the average for T. kanchil in all measured parameters; moreover, in external measurements it ap- 
Table 1. Comparison of external post-mortem measurements (in $\mathrm{mm}$ ) and body mass (in $\mathrm{g}$ ) of sympatrically occurring Tragulus versicolor and T. kanchil (range and average \pm standard deviation).

\begin{tabular}{|l|c|c|c|c|c|}
\hline $\begin{array}{l}\text { Species, sex } \\
\text { (sample size) }\end{array}$ & Head \& body & Tail & Hind foot & Ear & Mass \\
\hline $\begin{array}{l}\text { T. versicolor, male } \\
(\mathrm{n}=1)\end{array}$ & 400 & 50 & 110 & 35 & 1700 \\
\hline $\begin{array}{l}\text { T. kanchil, males } \\
(\mathrm{n}=8)\end{array}$ & $410-490$ & $60-90$ & $100-128$ & $35-45$ & $\begin{array}{c}1400-2300 \\
185 \pm 31.2\end{array}$ \\
\hline T. kanchil, females & $440-560$ & $65-85$ & $100-130$ & $35-50$ & $1600-3200^{*}$ \\
$\left(\mathrm{n}=6^{*}\right)$ & $490 \pm 41.2$ & $76 \pm 7.4$ & $119 \pm 9.9$ & $42 \pm 5.1$ & $2275 \pm 637.0^{*}$ \\
\hline
\end{tabular}

*The sample includes two females in late stages of gestation.

Table 2. Selected cranial measurements (in mm) of Tragulus kanchil from the vicinity of Buon Luoi.

\begin{tabular}{|l|c|c|c|c|c|c|c|c|c|c|c|c|c|}
\hline & CBL & BPL & ML & ZW & CW & NL & WB & MH & BW & BL & IB & UTL & DL \\
\hline $\mathrm{N}$ & 2 & 2 & 3 & 5 & 5 & 3 & 5 & 3 & 5 & 5 & 5 & 5 & 3 \\
\hline Min & 86.0 & 64.7 & 72.4 & 39.5 & 19.7 & 27.5 & 29.3 & 26.3 & 8.0 & 16.0 & 4.8 & 29.9 & 8.5 \\
\hline Max & 90.1 & 66.4 & 74.8 & 41.1 & 22.3 & 30.0 & 31 & 31.4 & 9.0 & 19.0 & 5.4 & 35.8 & 10.0 \\
\hline Avg & 88.1 & 65.6 & 73.7 & 40.5 & 21.0 & 28.7 & 30.4 & 29.3 & 8.5 & 17.6 & 5.1 & 33.7 & 9.3 \\
\hline SD & - & - & 1.21 & 0.72 & 1.09 & 1.25 & 0.64 & 2.17 & 0.37 & 1.26 & 0.24 & 2.23 & 0.76 \\
\hline
\end{tabular}

Explanations: N — sample size; Min — minimal value; Max - maximal value; Avg — average value; SD — standard deviation.

Measurements (essentially follow those of Meijaard \& Groves (2004) with the exception of UTL and LD): CBL condylobasal length; BPL — basipalatal length; ML — mandible length; ZW — zygomatic width; CW — condylar width; $\mathrm{NL}$ - length of nasal bones; WB - width of braincase; $\mathrm{MH}$ - mandible height; BW — width of tympanic bulla; BL length of tympanic bulla; IB — distance between tympanic bullae; UTL — upper cheek toothrow length; LD — length of the upper diastema.

proximately corresponds to the smallest specimen in the whole series. We cannot exclude, however, that the specimen in our possession is abnormally small, and despite that it appeared fully grown.

Given the lack of apparent overall size differences from T. kanchil, it is curious, why T. versicolor was initially placed in the synonymy of $T$. napu, which is significantly larger than any named form from the "javanicus" species group (e.g., Corbet \& Hill, 1992; Meijaard \& Groves, 2004). One possible explanation is that it was compared to the smaller southern forms of this group. Contrarily, in our sample these differences may be obscured by the somewhat unusually large size of $T$. kanchil. Selected measurements of available cranial material are provided in Tab. 2.

In general specimens of T. kanchil from Buon Luoi exceed the average skull dimensions provided by Meijaard \& Groves (2004) for the Indochinese mainland forms affinis Gray, 1861 and pierrei Bonhote, 1903 (which they synonymised), and also for the more southwestern extralimital subspecies fulviventer Gray, 1836, but rather approach the dimensions provided by these authors for another extralimital form ravus Miller, 1902 and even for T. williamsoni Kloss, 1916, which was raised to specific rank on the basis of exceptionally large size of the single measured specimen. Bearing in mind the possibility of bias imposed by individual patterns of taking measurements by different researchers, we may also suppose the presence of latitudinal increase in overall size in T. kanchil (e.g., as predicted by Bergman's rule) and suggest that further analysis of more comparative material from the central and northern parts of the Truong Son Range is required to clarify the taxonomical status of local populations of mouse deer and the relationships between the named forms affinis and williamsoni.

Close morphological similarity between $T$. kanchil and $T$. versicolor provides for the necessity of ecological and behavioral mechanisms facilitating sympatric coexistence of the two species without sufficient competitive interference. Unfortunately, no data is available on the capture conditions or habitat of the ZMMU specimen of $T$. versicolor, except that it was shot by local people during a nighttime hunt in tall forest in the Tra River valley.

The area around Buon Luoi was selected as a longterm study plot for joint Vietnamese-Russian expeditions in 1978 (Sokolov et al., 1982) through 1993. During the 1980s and 1990s the area surrounding the site was largely covered by relatively intact mature lowland semievergreen tropical forest with a complex tier structure comprising up to four or five storeys, with emergents reaching 40-50 m, the upper storey being over 20 $\mathrm{m}$ and lacking gaps in the canopy, whereas the understoreys were relatively free of dense thickets and forest floor was well-exposed and passable (Sokolov et al., 
1982; Stepanyan, 1995). This area is currently part of the Central Annamites Priority Landscape (CA1) for conservation, belonging to the Greater Annamites Ecoregion (Baltzer et al., 2001a, b).

In the vicinity of Buon Luoi most encounters with mouse deer (presumably T. kanchil) occurred in places where tall forest alternated with scrub thickets, patches of grassland and moist riverine habitats. Riverbank slopes appeared to be particularly favorable to chevrotains, due to the presence of fruiting trees, e.g., Ficus spp. Confinement to the forest floor and dietary preference for fallen fruit (Dang, 1968; Kuznetsov \& Puzachenko, 1992) eventually make mouse deer conspicuous for observing. Unfortunately, these same behavioral peculiarities also make them particularly vulnerable to nighttime hunting, which supposedly was the main cause of the decrease in population density by 1990 s, revealed by both nighttime surveys and qualitative assessments of the occurrence of footprints in the area of investigation (G.V. Kuznetsov, unpublished data). Nighttime surveys conducted near Buon Luoi in December 1978 revealed the occurrence of mouse deer asca. three individuals per $5 \mathrm{~km}$ of transect route. By 1993, when forest habitats underwent heavy degradation, the occurrence of chevrotains was less than one individual per night (at least 10 $\mathrm{km}$ of transect).

Nighttime hunting may also in part explain their virtual absence from uncluttered habitats in the area under consideration. Contrarily, in Cat Tien National Park (South Vietnam), where use of firearms has been banned for decades, chevrotains are encountered with comparable frequency both in thickets and on exposed forest floor (Borissenko \& Ivanova, 2003 unpublished report).

Conservation is indeed a very important issue regarding the status of $T$. versicolor in Vietnam (Baltzeret al., 2001; Meijaard, in press). The specimen in ZMMU leaves some hope that this species at least did not become extinct by the end of the 20th century and its distribution in the 1990s was not limited by the type locality only. However, there are no other records of unusually colored mouse deer from the vicinity of Buon Luoi. The total number of animals examined by various researchers within the period from 1978 to 1993 (24 T. cf. kanchil, compared to only one $T$. versicolor) indicates that the proportion of the latter species during that period did not exceed $5 \%$ of the overall chevrotain population. Similarly, there are no further materials on T. versicolor from the more southern parts of the Tai Nguyen Plateau, despite that it was quite extensively covered by joint Vietnamese-Russian expeditions and mouse deer were both encountered and collected there. It seems reasonable to suppose that careful reexamination of the collections of chevrotains in Vietnamese depositories should reveal further specimens of this species, however, it is unlikely to change the overall picture of its dramatically low abundance.

The reasons for the scarcity of $T$. versicolor remain unclear. At least three possible explanations may be put forward: 'naturally' low population density, exceptionally cryptic habits which may hamper nighttime hunting (and collecting) or, contrarily, confinement to exposed areas (e.g., uncluttered floor of tall primary forests), which may have caused $T$. versicolor to decline dramatically during the past century, due to excessive hunting pressure and/or deforestation. The latter possibility should be of special concern from the conservational standpoint. E.g., by mid 1990s the area around Dak Rong and Buon Luoi has been completely deforested and converted to agricultural landscape (G.V. Kuznetsov, personal observations). Fortunately, there are still protected areas in the region (Kon Ka Kinh and Plei $\mathrm{Ku}$ ). Also considerable patches of variously disturbed to nearly intact montane forest are still present to the west of Nha Trang (Khanh Hoa and Lam Dong Provinces; Kruskop \& Morozov, 2002; Borissenko, 2003); however, there is limited logging activity, and substantial hunting pressure is imposed on medium-sized forest floor inhabitants, primarily through snaring. Nighttime surveys conducted in the latter two areas (estimating the total survey effort as at least 100 hours) did not reveal the presence of any mouse deer (ibid.). At this point it is critical that the remaining forests near the type locality of $T$. versicolor and protected areas proximal to Buon Luoi are surveyed more extensively for its occurrence, and special conservation measures are employed to prevent logging and hunting by local people. Additionally, activities specifically aimed at finding this species should be encouraged in other geographically proximal areas with remaining mature forests.

ACKNOWLEDGEMENTS. Field studies of the senior author in Vietnam were facilitated by the Institute of Ecology and Biological Resources, Vietnam (director, Dang Huy Huynh), Vietnam and the Vietnam-Russian Science and Technological Tropical Centre (co-directors Tran Xuan Thu and V.S. Roumak). Immense help and support in organizing the expeditions and collecting field material was provided by Dang Huy Huynh, Cao Van Sung, Pham Trong Anh, Le Xuan Canh, Nguyen Xuan Dang, V.V. Rozhnov, K.S. Baranauskas and S.I. Isayev. We also thank E. Meijaard for his encouragement to publish our finding, for providing his unpublished data on $T$. versicolor and for comments on our manuscript. Further improvements to the text were made by A.A. Tikhonov and A.A. Lissovsky.

\section{References}

Baltzer M.C., Nguyen Thi Dao \& Shore R.G. (eds.). 2001a. Towards a Vision for Biodiversity Conservation in the Forests of the Lower Mekong Ecoregion Complex. Hanoi \& Washington: WWF Indochina/WWF US. 109 p.

Baltzer M.C., Nguyen Thi Dao \& Shore R.G. (eds.). 2001 b. Towards a Vision for Biodiversity Conservation in the Forests of the Lower Mekong Ecoregion Complex Technical Annex. Hanoi \& Washington: WWF Indochina/WWF US. 228 p.

Borissenko A.V. 2003. [A preliminary survey of the mammal fauna in Hon Ba proposed national park] // Vietnamese- 
Russian Tropical Centre (unpublished report). 18 p. [in Russian].

Borissenko A.V. \& Ivanova N.V. 2003. [Ecological observations on bats (Mammalia: Chiroptera) of Cat Tien National Park, with comments on non-volant mammals] // Ecological Studies in Cat Tien National Park (Dong Nai Province) in July 2002 - February 2003. Reports. Vietnamese-Russian Tropical Centre (unpublished). P. 65-94 [in Russian].

Corbet G.B. \& Hill J.E. 1992. The Mammals of the Indomalayan Region: A Systematic Review. Oxford: Oxford Univ. Press. 488p.

Dang Huy Huynh. 1968. [Some data concerning the biology of Tragulus javanicus affinis Gr. (Artiodactyla, Tragulidae) in the Democratic Republic of Vietnam] // Zoologicheskii Zhurnal. T.47. No.3. P.432-437 [in Russian, with English summary].

Kruskop S.V. \& Morozov P.N. 2002. A preliminary survey of the mammal fauna of the Bi Doup mountain massif, upper Da Nim River (Lang Bian Plateau) // Vietnamese-Russian
Tropical Centre (unpublished report). 10 p. [in Russian]. Kuznetsov G.V. \& Puzachenko Yu.G. 1992. [Food consumption, digestibility and certain forms of feeding behavior in the Javan chevrotain Tragulus javanicus under captive conditions] // Sokolov V.E \& Kuznetsov G.V. (eds.). [Materials of Zoological Research in Vietnam (19871990)] Moskva: Institut Evolutsionnoi Morfologii i Ekologii Zhivotnykh A.N. Severtsova. P. 39-46 [in Russian].

Meijaard E. \& Groves C.P. 2004. A taxonomic revision of the Tragulus mouse-deer (Artiodactyla)// Zoological Journal of the Linnean Society. Vol.140. No.1. P.63-102.

Meijaard E. \& Groves C.P. In press. Tragulus versicolor; the lost mouse-deer of Vietnam? // Oryx.

Sokolov V.E., Kuznetsov G.V., Cao Van Sung \& Dang Huy Huynh. 1982. [Theriological studies in Vietnam] // Medvedev L.N. (ed.). [Animal World of Vietnam]. Moskva: Nauka. P.5-22 [in Russian].

Stepanyan L.S. 1995. [Birds of Vietnam]. Moskva: Nauka. 447 p. [in Russian]. 